\title{
All Roads Lead to Homosociality: The Role of Chivalry in Medieval and Modern Society
}

\author{
Grace M. McDougall \\ Faculty Mentor: Dr. Karma Lochrie, Department of English, Indiana University Bloomington
}

\begin{abstract}
This paper examines the role of chivalry in Marie de France's lais, focusing on Guigemar with support from Bisclavret. One of the most-studied authors of the medieval period, Marie de France channels the values, anxieties, and societal dynamics of her time by both adhering to and pushing against literary norms. Guigemar and Bisclavret present near-perfect examples of knighthood according to chivalric norms, save for two flaws: Guigemar has no love for women, and Bisclavret is a werewolf. The treatment of these knights and their peculiarities reveals the strict expectations of masculinity and the risks of breaking from them. I pay particular attention to the importance of humility in chivalric masculinity and the ways in which their peculiarities affect their relationships, especially with other men. Guigemar shows that humility, rather than courage, martial skill, or courtesy, was the most important chivalric value. Humility is so essential because the main role of chivalry was to preserve the relationships between men that formed the basis of medieval society. I argue that understanding the cultural history of chivalry is important for modern audiences because the concept of chivalry is still used by many groups to legitimize and promote their interests and continues to shape our perceptions of masculinity and gender dynamics. While what we think of chivalry has changed greatly since Marie de France's time, the ends of chivalry remain the same-to promote the interests of those in positions of power.
\end{abstract}

\section{THE LIFE AND TIMES OF MARIE DE FRANCE}

66 $\bigcirc$ ne whom God has given knowledge / and good eloquence in speaking / should not keep quiet nor hide on this account / but

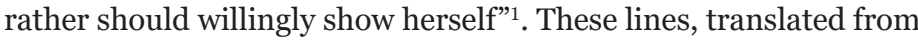
old French to modern English, begin the general prologue to Marie de France's collected lais. Marie de France wrote for the court of Henry II and Eleanor of Aquitaine in the late twelfth century, and the lais that are the focus of this paper are a category of short, narrative poems that originated through oral storytelling in Brittany. While not much of Marie de France herself is known, her works have endured as containing some of the most delightfully unique moments in medieval literature. Love, specifically between noble men and women, is the central theme that pervades all of the stories. The ways that Marie de France depicts love are all drastically different-what is condemned or ridiculed in one lai is celebrated and praised in the next. These variations in representation are possible because of Marie de France's strong attention to specific socio-cultural context. Common themes of scholarship on the lais include courtly love, gender dynamics, and male relationships. Jenny Adams' work "Pieces of Power: Chess and Male Homosocial Desire" examines the similarities in another of the lais between heterosexual love and vassalage ${ }^{2}$ and the importance of bonds between men $^{3}$. The lais' emphasis on social ties provides the opportunity to consider how relationships between men formed the fabric of medieval society and how, in particular, chivalry functioned to regulate these relationships.

The period in which Marie de France wrote is sometimes considered the beginning of the High Middles Ages, and it was during this time that chivalry in England fully developed into a social and cultural ideal. The development of chivalry in England began in 1066 when William the Conqueror introduced the style of fighting on horseback and a new military code of conduct. This code of conduct, which medieval historian Nigel Saul argues is the beginning of chivalry, arose from the nobility's need for self-

\footnotetext{
Claire M. Waters, The Lais of Marie De France Text and Translation (Petersborough, Broadview Editions, 2018), lines 1-4.

2 Jenny Adams, "Pieces of Power: Medieval Chess and Male Homosocial Desire," The Journal of English and German Philology 103, no. 2 (2004): 201.

"Adams, "Pieces of Power," 203
}

preservation amid incessant warfare on the Continent. Some of its tenets included treating prisoners fairly and minimizing bloodshed after victory was secured ${ }^{4}$. In the eleventh century, a religious component of chivalry emerged as the Church began to consider knights as warriors of Christianity and used them to further their interests, as evidenced by the crusades. The last aspect of chivalry, courtesy, developed in the twelfth century. By the time that Marie de France was writing, chivalry had risen to an ideal that greatly influenced and was influenced by the culture and art of the time.

There is, of course, a great difference in how chivalry existed as an ideal and how chivalry functioned in everyday reality-what some knights and authors wanted chivalry to be and what knights actually were. A critical tension within chivalry is the need to promote martial prowess as a means to retain and gain power through military success, while also restraining violent impulses to prevent excessive violence, social destabilization, and mutual self-destruction. So, while depictions of knights and chivalry may focus more on personal glory and the virtues used to acquire it, such as courage or martial prowess, when we look to chivalry's origin as a means to mutual self-preservation, humility emerges as the most important chivalric value. Humility is motivated by dependence on others, by helplessness, rather than the acquisition of glory. It is this recognition of dependence that sustains homosocial bonds.

Medieval society was largely homosocial, meaning that the most important relationships that created power and that either created or destroyed social stability were between men. Marianne Ailes writes, "[m]en were largely defined...by their relationships with other men-father and son, lord and vassal" ${ }^{5}$, and Harriet Spiegel notes that another of Marie de France's works, the Fables, presents a male power hierarchy as both a representation and a critique of her own patriarchal society ${ }^{6}$. Chivalry and its composite values reflect the centrality of the homosocial bonds between a lord and his knights-the knights' military prowess helps the

\footnotetext{
Nigel Saul, "The Origins of English Chivalry," in Chivalry in Medieval England (Cambridge: Harvard University Press, 2011), 10.

Marianne Ailes, "The Medieval Male Couple and the Language of Homosociality," in Masculinity in Medieval Europe, ed. D. M. Hadley (New York: Taylor \& Francis, 1999), 214.

"Harriet Spiegel, "The Male Animal in the Fables of Marie de France," in Medieval Masculinities: Regarding Men in the Middle Ages, ed. C.A. Lees, T.S. Fensters, J. McNamara (Minneapolis: University of Minnesota Press, 1994), 151.
} 
lord gain and retain territory, the lord's generosity ensures that he protects and supports his knights, and humility makes it so that all parties maintain their obligations. Even situations that seemingly privilege bonds between men and women truly promote relationships between men. A key example of this dissonance in medieval culture and literature is courtly love. Courtly love is the process by which a noble man wins over a noble woman through grand acts of bravery and service, which supposedly elevates the woman to a position of power; however, many medieval scholars have argued that the importance of the lady does not hold below the surface. Ruth Karras argues that despite its performative heterosexuality, the real end of courtly love is to further homosocial posturing and bonding 7 ; women create the excuse for action that is intended to be viewed by other men.

This reading of courtly love fits in with Eve Sedgwick's larger theory of male homosociality. Sedgwick defines male homosocial desire as the "social force, the glue" that shapes relationships between men ${ }^{8}$. One foundational concept in Sedgwick's work is the erotic triangle, meaning the situation in which a woman is the object of desire for two men and the two men are rivals for the woman's affection ${ }^{9}$. Sedgwick cites René Girard's observation that although the bonds between "lovers and the beloved" seem as though they should be the strongest in this configuration, the bonds between rivals are actually stronger and more active $\mathrm{e}^{10}$. The woman is merely a conduit to support interactions and bonds between men. Marie de France's Guigemar portrays this dynamic between heterosexuality and homosociality with interesting implications about medieval society.

\section{SUMMARIES OF GUIGEMAR AND BISCLAVRET}

The titular knight of Guigemar, though highly successful in battle, has one critical flaw-his lack of interest in women. He comes across a magical white deer while hunting one day and fires an arrow at her. The arrow wounds the deer and then ricochets back to stab him through the thigh, a symbol of castration in medieval literature. The deer curses Guigemar that his wound will never heal until he falls in love with a woman and they both suffer greatly for their love. Guigemar sets out alone in search of a cure and is transported by a magical ship to a mysterious castle. There he meets a lady and falls in love, but they are separated when her jealous husband discovers them. Before they part ways, they promise to find each other, symbolized by their putting a knot in each other's clothing that only they can undo. The lady escapes from her husband to search for Guigemar after he has left and returned to his homeland. She is eventually abducted by a lord named Meriaduc who lusts greatly over her, even after she denies him multiple times. Guigemar then visits Meriaduc's castle, and Guigemar and the lady are at last reunited. Meriaduc, however, even after hearing their story, refuses to give up his advances on the lady, prompting Guigemar to go to war against him and ultimately kill him.

Bisclavret is a werewolf who spends many nights roaming the woods in his wolf form. After his wife grows suspicious of his frequent absences, Bisclavret finally tells her his secret. Horrified, his wife plots with another knight, and together, they steal his

\footnotetext{
${ }^{7}$ Ruth Karras, "Mail Bonding: Knights, Ladies, and the Proving of Manhood," in From Boys to Men: Formations of Masculinity in Late Medieval Europe (Philadelphia: University of Pennsylvania Press, 2003), 21.

${ }^{8}$ Eve Sedgwick, "Gender Asymmetry and the Erotic Triangle," in Between Men: English Literature and Male Homosocial Desire (New York: Columbia University Press, 1985), 21.

${ }^{9}$ Ibid., 21.

${ }^{10}$ Ibid.
}

clothes so that he will be trapped in his wolf form. The wife then marries the other knight once Bisclavret is presumed dead. Bisclavret is finally saved when the king of the land finds him in the forest and, impressed by his human-like qualities, takes him back to the castle. While at the castle, Bisclavret sees his wife and bites off her nose. Because Bisclavret had been so gentle before, the king assumes that the wife is guilty of some crime, and, after questioning her, the truth of her betrayal is revealed. Bisclavret transforms back to a man, his wife is banished, and the king rewards him with gifts of land.

Ultimately, Guigemar shows the transformation of a social nonconformist who is violently forced to participate in chivalric social norms into himself a violent enforcer of chivalric expectations. Bisclavret serves as a good supporting text to Guigemar because, unlike Guigemar, Bisclavret is an ideal model of knighthood throughout the lai. Both lais concern themselves with chivalry and demonstrate how the chivalric value of humility promotes male homosocial bonds. If Guigemar is the story of a man forced to practice humility to ensure the continuation of homosocial bonds, then Bisclavret shows the prosperity and stability that homosocial bonds can bring when maintained by humility.

\section{CLOSE READINGS}

Guigemar's lack of interest in women indicates the larger issue of his disinterest in homosocial bonds. The root of the problem is his independence. Marie de France attributes to Guigemar the customary values of chivalry, beauty, courage, and martial talent, and gives credence to these claims through other people's reactions. Not only do his parents and sister love him, when he goes away to train at court, "he made himself well-loved by all"11. His singular flaw is that "he never had any interest in love" 12 . In the following lines, Marie de France specifies that he has no desire for women, but the original statement also suggests that, more broadly, he is not interested in forming key social bonds. As a knight, he requires a lord to ennoble him and support him financially, but once he is knighted, he is able to "seek glory in Flanders"13, and wherever he goes, no one could "find at that time / so good a knight, or one who was his peer"14. Guigemar is such an exemplary knight that in fulfilling the expectations of chivalric masculinity, he ends up going against the code's purpose, which is to cement social bonds and ensure that people remain loyal to one another. He has no weakness that would force him to be dependent upon others. Even after he has been cursed by the white hind and is in severe pain, he intentionally leaves without any of his men because "he did not want any of his men to come / who might trouble him or hold him back"15. Furthermore, while hunting today is considered a very homosocial activity, some in Marie's time considered it a solitary and selfish pastime, adding to the sense of Guigemar's asociality, as William Burgwinkle notes ${ }^{16}$. The stag's curse that Guigemar "will never have a remedy! / Neither from herb nor root, / neither from doctor nor potion / will you find healing"17 uses heterosexuality as a mechanism, the purpose of which is to force him to experience crippling helplessness that can only be remedied through a social bond. Guigemar cannot lift the curse through any transactional or material solutions; he must engage in a relationship with a woman for which they both will suffer deeply.

\footnotetext{
${ }^{11}$ Claire M. Waters, "Guigemar," in The Lais of Marie De France Text and Translation (Petersborough, Broadview Editions, 2018), line 44.

12 Ibid., 1. 58.

${ }^{13}$ Ibid., 1. 51

${ }^{14}$ Ibid., ll. 55-56.

${ }^{5}$ Ibid., ll. 143-144.

${ }^{16}$ William Burgwinkle, "Queering the Celtic: Marie De France and the Men Who Don't Marry," in Sodomy, Masculinity, and Law in Medieval Literature (Cambridge: Cambridge University Press, 2004), 154.

${ }^{7}$ Waters, "Guigemar," 11. 109-112.
} 
The language of the hind's curse presents a conventionally homosocial dynamic that suggests that the heterosexual relationship between Guigemar and the lady is a proxy for more favored homosocial ties. Guigemar's immediate reaction to the hind's curse is entirely focused on survival. As a knight, he is accustomed to bloodshed, so that he was "frightened by what he hears" 18 and "does not want to let himself die"19, shows how dire the situation is. Although hunting is a common metaphor for the pursuit of love, Guigemar's literal wound and the impending threat of death create stakes more comparable to those of a battlefield. In such a situation, Guigemar should be accompanied by his comrades-in-arms, but he intentionally leaves without them. The lady fulfills that role in some ways, as suggested by the lines, "she shall heal you / who will suffer, for love of you, / such great pain and sorrow...and you will do as much for her" ${ }^{20}$. In many courtly romances, men undergo great feats of strength and bravery to prove their devotion for a woman, as is the case in Chretien de Troyes' later work The Knight of the Cart, in which Guinevere creates humiliating situations to test Lancelot's love. The woman is an observer and does not undergo similar tests of character, which makes sense if the unstated goal of courtly love is for men to gain honor. However, in the language of the curse, Guigemar and the lady undergo equal trials and are equally glorified. In this sense, they are acting more as comrades-in-arms who support each other in the pursuit of a common goal. The curse renders him helpless, thereby forcing him into a heterosexual relationship that is a proxy for more socially-valued homosocial bonds in which he had not previously needed to participate.

Guigemar and his lady are helpless not in the sense that they are entirely without agency, but in that they can alleviate their suffering only through each other. As the story progresses, Guigemar gradually depends more and more on others, modeling a traditional initiation ritual $^{21}$. When he first embarks on his search for a cure, he acts as someone entirely independent, but the encounter with the enchanted ship strips him of all control. When he awakens, the ship is at sea, and he "is very sad, he does not know what to do"22, so he "prays to God that he take care of him" ${ }^{\text {"23 }}$. In this moment, Guigemar is performing the chivalric value of piety, and his admission of his helplessness and supplication to a higher power is the first step towards the development of humility. Once he arrives at shore and is discovered, he begs the lady, "in God's name, / advise me, by your mercy! / For I do not know where to go, / nor can I steer the ship"24. Guigemar does not know that this is the woman with whom he will fall in love, and he depends on her not for love but for the knowledge which he sorely lacks. Guigemar's emotional response, after they do fall in love and finally admit their feelings, is "ease," ${ }^{25}$ which, while positive, suggests a happiness derived from the loss of something negative rather than the gain of something positive. Love allays pain rather than creating pleasure.

Extending the idea that this forced heterosexual relationship stands in for preferred homosocial bonds, all meaningful social ties are formed to alleviate painful conditions. That the first words that Guigemar ever says to the lady are a plea for mercy encapsulates this process. People create bonds because they are forced to do so by need, such as Guigemar's need for knowledge; knights, lords, and kings all depend on each other for their continued survival. If a knight, such as Guigemar, over-excels at chivalric values, without the temperance of humility, then the

\footnotetext{
${ }^{8}$ Ibid., 1. 124.

${ }^{19}$ Ibid., 1. 128.

${ }^{20}$ Ibid., ll. 114-118.

${ }^{21}$ Burgwinkle, "Queering the Celtic," 153.

${ }^{22}$ Waters, "Guigemar," l. 194.

${ }^{23}$ Ibid., 1. 200.

${ }^{24}$ Ibid., ll. 333-336.

${ }^{5}$ Ibid., 1. 530.
}

purpose of the chivalric code, namely to ensure that people will remain loyal and draw each other out of mutual helplessness, is completely undercut. If those in power want to maintain it, then the overly independent must be rendered helpless for the preservation of social order.

Like Guigemar, Bisclavret is defined by his abnormality, but his is less severely framed and he is not punished for it; rather, Bisclavret's abnormality highlights his nobility and, above all else, his humility. Guigemar's abnormality is prefaced by the line: "[o]nly in this did Nature make a mistake with him" ${ }^{26}$. To make a mistake or err is mepris in French, but it is debatable who, between Guigemar and Nature, is the subject and object. Because of ambiguity in the original French, another possible translation, though less frequently used, is that it was Guigemar who made the mistake against Nature; this is discussed in a footnote in Waters' translation ${ }^{27}$. In Bisclavret, Marie de France portrays werewolves as wild and destructive but then dismisses the mythology with the line, "[n]ow I let this matter be" ${ }^{28}$, as she moves on to write about "a worthy man / whom I have heard marvelously praised”29. Marie de France separates Bisclavret's reputation from the lore, suggesting that he will go against the expectations of beastliness. This distance contrasts with Guigemar who, under either interpretation of the "mistake," is directly implicated. He has either erred against Nature, or Nature has created him flawed. Even though it seems that Bisclavret, who is not fully human, should be more at odds with Nature than Guigemar, such a trespass is never indicated, foreshadowing that, unlike Guigemar, Bisclavret will not be intentionally punished.

Humility is such an important component of chivalry that Bisclavret's humility makes his inner humanity recognizable even through his beastly form. When the king's dogs attack Bisclavret in the forest, Bisclavret kisses the king's foot, prompting the king to exclaim, "how this beast humbles itself! / It has human understanding, it begs mercy" ${ }^{30}$. Here, Bisclavret does what Guigemar was initially unable to do-he acknowledges his helplessness and seeks a bond. The king's logic reveals that the capacity for humility, the ability to beg for mercy, is uniquely human. The king sees the humanity within Bisclavret despite his beastly form because of his humility. Thomas Schneider writes that metamorphoses in which knights transform into animals are common throughout Marie's work, and the mutability of form serves to emphasize in contrast a "static masculinity: a concrete picture of what it means to be male and a knight, so solid that it remains constant even in physical transformations out of and into humanity" ${ }^{31}$. Humility is so essential to chivalry that Bisclavret, because of his displays of humility, is recognizable as a knight even when he is literally not human. Humility is so important that it transcends physical form. Furthermore, while Bisclavret's static masculinity is validated by comments that he is "noble and kind"32 and that "there is no one who does not hold it dear"33, which mirror the way in which he was described at the beginning of the story, these traits of nobility and kindness are secondary. It is only after the king recognizes Bisclavret's humility that his other traits and nobility become visible, indicating that of all the chivalric qualities, humility is the most important.

By the end of the lai, Guigemar has become fully entrenched

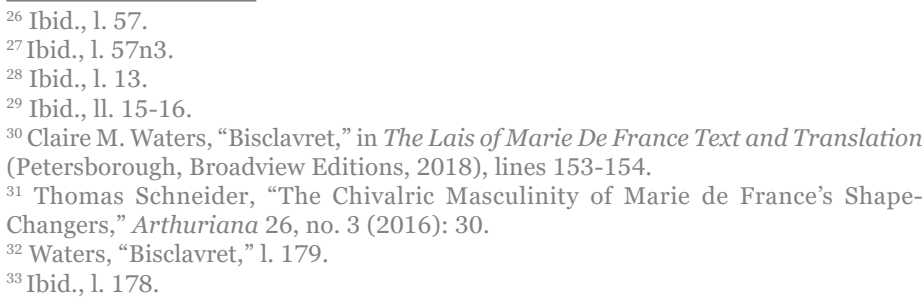


in homosocial society. The lady, after Guigemar leaves, sails to Guigemar's homeland, where a lord named Meriaduc abducts her to his castle. Simultaneously, Meriaduc is at war with a neighboring lord, and he calls upon many knights to come to his aid, including Guigemar. Meriaduc asks him, "as a friend and companion, / not to fail him in this need" 34 . Here we see a conventional homosocial bond between Guigemar and Meriaduc. Meriaduc is obliged to call upon Guigemar out of a need for more men, and Guigemar reciprocates, thus satisfying Meriaduc's need. The homosocial bond breaks down, however, once Meriaduc refuses to stop his pursuit of the lady. Guigemar responds as he should-he exercises humility and initiates a homosocial bond in order to satisfy a need. His humility is shown by his plea for "mercy" 35 , and the proposed bond is that he will become Meriaduc's "liege man...serve him for two or three years / with a hundred knights or more" 36 . Meriaduc's refusal breaks with chivalric code and disrupts the societal foundation of homosocial bonds. His earlier request that Guigemar come to his aid shows that he is at least partially dependent upon Guigemar. Thus, in order to preserve this bond and his own self-interest, he should reciprocate by honoring Guigemar's request to "restore" 37 the lady to him. Meriaduc's refusal stems from a lack of humility, as the root of humility is a recognition of one's dependence upon others, and it is a dangerous breach of the chivalric code which preserves social stability. In response to Meriaduc's betrayal, Guigemar "destroyed and captured the castle / and killed the lord within" 38 . Guigemar not only kills Meriaduc, he eradicates his ties to nobility and power by capturing his castle, which is fitting since the chivalric system that Meriaduc has violated is there to preserve the nobility's high status. Guigemar is now so entrenched in chivalric code that he violently enforces it.

Some critics have argued that Guigemar's violent ending reflects anxieties about social stability. Joan Brumlick, for example, argues that Guigemar expresses concerns about feudal crisis caused by unfulfilled marital responsibilities. A key function of heterosexual marriages was to create heirs to carry on dynastic lines. Guigmar, though entangled in a heterosexual relationship, shows no intentions to marry. One common ending for romances is marriage, but Marie de France makes no mention of it at all. Brumlick writes that Guigemar's "excessive display of violence towards not only Meriaduc, but also many innocent people" represents the societal destruction that his refusal to marriage threatens ${ }^{39}$. While this nuanced interpretation raises interesting questions about medieval societal anxieties, the heterosexual relationship between Guigemar and the lady has faded to the background by this point in the lai. Returning once again to Sedgwick's writing on male homosociality, women and homosexual relationships primarily function to promote bonds between men. Guigemar is forced into a heterosexual relationship not because of the inherent value of heterosexual relationships but because it will foster homosocial bonds. Early in the story, when Guigemar is still learning how to be humble, he and the lady are described on equal terms - they must both suffer equally for their love. Once Guigemar has learned to be humble, however, and the two lovers return to larger medieval society, the lady is no longer an equal but an object that facilitates interaction between Meriaduc and Guigemar. It is true that the unanswered question of Guigemar and the lady's relationship lingers at the end of the story, but it

\footnotetext{
${ }^{34}$ Waters, “Guigemar,” ll. 750-751.

35 Ibid., 1. 842.

${ }^{36}$ Ibid., ll. 843-845.

${ }^{37}$ Ibid., 1. 842.

38 Ibid., 1l. 879-880.

${ }^{39}$ Joan Brumlick, "Thematic Irony in Marie de France's Guigemar," French Forum

13, no. 1 (1988): 12
}

is secondary to Guigemar's participation in and enforcement of chivalric norms in service of male homosociality.

Bisclavret, in contrast to the violence of Guigemar, depicts the stability and prosperity that male homosocial bonds maintained by humility create. Marie de France presents this philosophy in Guigemar: "[o]ne who can find someone loyal / should serve and love that person well / and be at his command" 40 . While these lines are in the context of heterosexual love, the language is ambiguously gendered and emphasizes service. In this ideal relationship, one is explicitly masculine, as it is "his command," but the other party, the subject of the sentence, is not gendered, making it applicable to any reader. Another moment of openness is the reference to the masculine party as "that person." Again, while framed by heterosexuality, the masculine party is not specified as a lover or husband, indicating that this advice holds true to any relationship, including homosocial bonds. The words "serve" and "loyalty" emphasize stability through pledges and the fulfillment of needs, all of which are exemplified by Bisclavret and his king. In return for Bisclavret's show of humility, the king orders everyone to treat Bisclavret well even when he believes him to be a beast. When Bisclavret has transformed back into a man, found asleep "[o]n the king's own bed" 41 , the king then "returned all his land to him; / he gave him more than I can say" 42 . Both quotations have connections to marital traditions. Beds are commonly associated with sex and romance, and the bed in Bisclavret draws upon these connotations, suggesting intimacy between the Bisclavret and the king. Bequeathing lands falls within a king's conventional host of powers, but another prominent way in which lands are exchanged is through marriage. The relationship between Bisclavret and the king can, of course, be read as more homosexual than homosocial, but however one interprets it, the bond between men has rectified the betrayal done unto Bisclavret by his wife. Homosocial bonds, first initiated through Bisclavret's humility, are a source of stability and prosperity.

The social dynamics in Guigemar and Bisclavret shed light on the balancing act of increasing and maintaining control in medieval Europe. Chivalric masculinity is key to this balance as it must achieve two contradictory aims-foster capable knights who strengthen their lord through military victories and prevent those same knights from gaining enough power to rebel. The cruel treatment of Guigemar indicates exactly how much of a threat independent knights posed. While knights certainly held higher status and privileges than the peasant women whose respect and dignity were blatantly ignored by chivalric codes, those codes were not intended to serve them either. Conventions and obligations, whether homosocial, heterosexual, or otherwise, serve only those at the very pinnacle of the social hierarchy. While the aspects of chivalry have changed greatly, the ways in which people use and define chivalry to suit their intentions remains the same.

\section{THE CASE FOR MEDIEVAL STUDIES: HOW REDUCTIONISM AND REVISIONISM AFFECT US TODAY}

The medieval period continues to have an enduring grasp on our cultural consciousness as the reductionism that shapes our view of the Middle Ages in turn shapes our conceptions of love, masculinity, and gender dynamics. The 1987 Marine Corps recruitment commercial "Knight", the recent series of

\footnotetext{
${ }^{40}$ Waters, "Guigemar," 1l. 493-495.

${ }^{41}$ Waters, "Bisclavret," 1. 298.

${ }^{42}$ Ibid., 1l. 303-304.
} 
"Dilly Dilly" Bud Light commercials, and the popular Game of Thrones television series show that any party can use medieval symbolism to sell their audiences something, whether it be the idea that serving in the Marines is a noble pursuit, a six pack of beer, or the box set of a TV show. While these examples may seem innocuous, groups have also embraced medieval symbolism, or medievalism, to sell something much more pernicious. The most prevalent medieval concept in our culture today is arguably chivalry, which we now primarily associate with the supposed respect and protection of women. A key voice in the discourse surrounding modern medievalism and, in particular, chivalry is medievalist Amy Kaufman. Chivalry has been used to justify a range of actions from a North Carolina charter school's dress code that required girls to wear skirts in order to "preserve chivalry and respect among young men and women" 43 to the Ku Klux Klan's framing of hate crimes as a crusade to protect white women from "dangerous black men" 44 . Not only did medieval chivalry seek to protect just a small subsection of women and only under a specific set of circumstances, it was also often unconcerned with the wellbeing of women. Modern invocations of chivalry typically either strip women of agency, as Richard Utz points out in his piece in response to former White House Chief of Staff John Kelly's comments on the sacredness of women ${ }^{45}$, or they use concern for women to legitimize an otherwise unrelated venture.

The Middle Ages are more dynamic, more diverse, and, even, longer than we know imagine them to be. Searching for a singular notion of how concepts such as chivalry were defined and enacted is impossible, but the study of medieval texts, such as Marie de France's lais, does give readers a better understanding of the variety of ways that concepts like chivalry did function throughout the Middle Ages. Moreover, such study reveals exploitations of medieval symbolism for what they are and facilitates further analysis of our own modern values.

\section{ACKNOWLEDGEMENTS}

The author would like to thank Karma Lochrie for supporting the writing and research of this manuscript and for sharing her passion for medieval literature.

\section{AUTHOR INFORMATION}

All correspondence should be sent to the first author:

gmmcdoug@iu.edu.

\section{REFERENCES}

Adams, Jenny. "Pieces of Power: Medieval Chess and Male Homosocial Desire." The Journal of English and German Philology 103, no. 2 (2004): 197-214.

Ailes, Marianne. "The Medieval Male Couple and the Language of Homosociality." In Masculinity in Medieval Europe, edited by D. M. Hadley, 214-237. New York: Taylor \& Francis, 1999.

Brumlick, Joan. "Thematic Irony in Marie de France's Guigemar.” French Forum 13, no. 1 (1988): 5-16.

\footnotetext{
${ }^{43}$ Kayla Epstein, "Girls were forced at school to wear skirts at school to "preserve chivalry.' So they sued-and won,” The Washington Post, March 30, 2019.

${ }^{44}$ Amy Kaufman, "Anxious Medievalism: An American Romance," The Years Work in Medievalism 22 (2008): 10.

${ }^{45}$ Richard Utz, "Were women ever sacred? Some medieval and modern men would like us to think so," Medievalists.net, http://www.medievalists.net/2018/10/werewomen-ever-sacred/
}

Burgwinkle, William. "Queering the Celtic: Marie De France and the Men Who Don't Marry.” In Sodomy, Masculinity, and Law in Medieval Literature, 138-69. Cambridge: Cambridge University Press, 2004.

Epstein, Kayla. "Girls were forced at school to wear skirts at school to 'preserve chivalry.' So they sued-and won." The Washington Post. March 30, 2019.

Karras, Ruth. "Mail Bonding: Knights, Ladies, and the Proving of Manhood." In From Boys to Men: Formations of Masculinity in Late Medieval Europe, 20-67. Philadelphia: University of Pennsylvania Press, 2003.

Kaufman, Amy. "Anxious Medievalism: An American Romance." The Years Work in Medievalism 22 (2008): 5-13.

Saul, Nigel. "The Origins of English Chivalry." In Chivalry in Medieval England, 7-20. Cambridge: Harvard University Press, 2011.

Schneider, Thomas. "The Chivalric Masculinity of Marie de France's Shape-Changers." Arthuriana 26, no. 3 (2016): 25-40.

Sedgwick, Eve. "Gender Asymmetry and the Erotic Triangle." In Between Men: English Literature and Male Homosocial Desire, 21-27. New York: Columbia University Press, 1985.

Spiegel, Harriet. "The Male Animal in the Fables of Marie de France." In Medieval Masculinities: Regarding Men in the Middle Ages, edited by C.A. Lees, T.S. Fenster, and J. McNamara, 111-126. Minneapolis: University of Minnesota Press, 1994.

Utz, Richard. "Were women ever sacred? Some medieval and modern men would like us to think so." Medievalists.net. October 14, 2018. http://www.medievalists.net/2018/10/ were-women-ever-sacred/

Waters, Claire M., editor, translator. "Bisclavret." The Lais of Marie De France Text and Translation, by Marie de France, 145-161. Petersborough: Broadview Editions, 2018.

Waters, Claire M., editor, translator. "Guigemar.” The Lais of Marie De France Text and Translation, by Marie de France, 53-99. Petersborough: Broadview Editions, 2018. 
